\title{
ELABORATING THE ROLE OF NETWORK SYNERGY CAPACITY AS A SUPPLIER'S ALTERNATIVE TERMINAL FOR ACHIEVING MARKETING PERFORMANCE
}

\author{
Ahmad Ikhwan Setiawan* \\ Universitas Sebelas Maret \\ Ahmad Hanfan \\ Universitas Diponegoro
}

\begin{abstract}
This research aims to construct a model of network synergy capacity in order to fill the research gap between trustdeveloping capability and marketing performance. This research model involves a number of other important supporting variables such as competitive position strengthening and excellent service commitment to improve marketing performance. At the beginning, 320 companies which distribute industrial products in Indonesia were contacted for the study using a purposive sampling technique. To achieve normality of data distribution, it was 263 respondent selected to be processed using AMOS. Our research indicated that the level of goodness of fit for the model meets all the necessary conditions and all the hypotheses proposed are supported. Even though network synergy capacity, in some pathways, has terminal role for increasing marketing performance but it is not as important as function of other variables, competitive position strengthening and excellent service commitment. Network synergy capacity as the novelty of this study contributed towards enhancing the body of knowledge of the network theory.
\end{abstract}

Keywords: Network Synergy Capacity; Trust-developing Capability; Competitive Position Strengthening; Excellent Service Commitment; Marketing Performance.

\section{INTRODUCTION}

In the face of increasingly fierce business competition, every company should have the ability to establish relationships. The success of a company is not defined by the extent to which the company is able to fulfill all the business requirements with its internal resources, but rather to what degree its external business network can be synergized to create a variety of valuable resources (Batonda \& Perry, 2003; Claro \& de Oliveira Claro, 2011). Conducting all its own resources requires a much larger investment than the use of outsourcing (Kim, Kim, Pae, \& Yip, 2013; Siguaw, Simpton, \& Baker, 1998). A company should establish cooperation with other companies that have specific advantages so that it is able to create its own new advantages (Todeva \& Knoke, 2005). Every company focuses primarily on selling products at a competitive price by managing the procurement of products efficiently. If companies are able to work with suppliers that offer products at competitive prices, they will be able to sell products at a cheaper price than their competitors. A company should establish cooperation with retailers who are able to market the company's products effectively (Tournois, Sahay, Sahay, \& Waheed, 2010; Sheu, Yen \& Chae, 2006). Companies that have a wide cooperation network with various other

*Corresponding author: Management Department, Faculty of Economics and Business, Universitas Sebelas Maret, Surakarta, Indonesia. Tel-062-271-743349. Email : aikhwansse@ gmail.com 
companies are able to develop local markets and create innovative marketing programs (Claro \& de Oliveira Claro, 2011; Westerlund \& Rajala, 2010).

Trust-developing capability is the main foundation in establishing business with customers (Izquierdo \& Cillian, 2004; Jambulingam, Kathuria, \& Nevin, 2011; Morgan \& Hunt, 1994). Trust-developing capability supports any business relationship because trust is the prerequisite for activities of benefit and risk sharing (Hsu \& Kannan, 2008). The more risky a business, the greater the company's need for a partner who can be trusted. The various skills that the company has developed in collaboration have effective expediency if business trust has been established among the parties involved in the business relations (Ha, Park, \& Cho, 2011). Business persons hope that the business relationships they form with partners will last for a long time so they endeavor to cooperate with parties that have a good reputation (Wagner, Coley, \& Lindeman, 2011). Meanwhile, business that is short-term oriented may not necessarily require knowledge of the track record of its partners because it only involves limited activities that have already been agreed upon (Izquierdo \& Cillian, 2004; Li \& Ogunmokun, 2001).

Various studies have shown a very strong argument for the effect of trust-developing capability on marketing performance (Ahimbisibwe et al., 2012; Ha et al., 2011; Jones et al., 2008; Kannan and Tan, 2006; Terpend et al., 2011). Companies which possess trust-developing capability are able to convince the customer that they have advantages that the customer needs (Kannan \& Tan, 2006). Companies which that have a high trust-developing capability find it easier to achieve a better marketing performance. Trust-developing capability enables companies to maintain customer loyalty which has a direct impact on improving marketing performance (Kannan and Tan, 2006). Companies are able to maintain professional behavior and receive a similar response from business partners in the form of an increased number of purchasing orders (S. C. Jones et al., 2008). Companies that build relationships of fairness seek to establish cooperation relationships that lead to increased sales (Terpend et al., 2011). The more experienced a company is in maintaining the trust business, the greater the area of the market that is able to be served by the company (Ahimbisibwe et al., 2012).

Several studies have formed different conclusions about the relationship between trust-developing capability and marketing performance (Ambrose, Marshall, \& Lynch, 2010; Corsten \& Felde, 2005; Jambulingam et al., 2011). A company's ability to build business trust does not affect its marketing performance (Corsten \& Felde, 2005). Companies that manage to build trust open the gateway to cooperation but they also need to establish real relationships through a real cooperation agreement. Trust positively affects the perception of the business partners regarding the specific advantages of the company. Nonetheless, trust is not able to generate an increase in the positive perception of marketing performance if it fails to encourage both sides to have the courage to carry out activities of shared risk (Jambulingam et al., 2011). Trust between companies and customers does not have the ability to make a certain level of sales volume achievable if there is an incompatibility in the business competences of the two parties (Ambrose et al., 2010).

The contradiction provoked the idea for a need to discover a mediating variable that is capable of bridging the relationship between the capability of developing business trust and marketing performance. Cooperation requires an attitude of equality and dependence of both suppliers and customers so that neither party suppresses the other party (Laeequddin \& Sardana, 2010). Various studies have shown that variables which contain the definition of collaboration, alliance (S. L. Jones, Fawcett, Fawcett, \& Wallin, 2010) or synergy (Connell \& Voola, 2007) are often used as an incentive for mutualistic cooperation (Sheu et al., 2006; Smart \& Dudas, 2007; Todeva \& Knoke, 2005). In the context of this research, a new variable was developed which is referred to as network synergy capacity. 
This study elaborates on business relationship from the perspective of suppliers in distributing of industrial goods to retailers. In industrial marketing, the supplier is often referred to as the company which distributes products to retailers while the retailer which acquires products from suppliers to market to end-users is referred to as the consumer (Izquierdo \& Cillian, 2004; Kim et al., 2013; Turner, LeMay, Hartley, \& Wood, 2000). Industrial products in this study are limited to a range of products: building materials, food and beverages, garments, chemical products, and electronics. Successfully of the product distribution sustain Indonesia's policy for industries development which influenced by increasing in certain sectors such as infrastructure-services, media \& information technology, fast moving consumer goods, technic \& manufacture and construction \& property.

Based on the above idea, the research objective is identifying the important role of network synergy capacity for achieving marketing performance. There are several pathways for achieving marketing performance through number of intervening variables such as competitive position strengthening and excellent service commitment. Using some statistical analyses, it will be discovered how important the role of network capacity synergy is as a bridge for achieving indicators of marketing performance: sales volume, market share, and sales value. Finally, some recommendations for suppliers in developing the distribution of industrial products are proposed.

\section{LITERATURE REVIEWS}

\subsection{Network synergy capacity}

The concept of network synergy capacity is constructed from three basic theories: relationship marketing, dynamic capabilities, and social capital. Relationship marketing departs from the theory of social exchange and discusses the factors that encourage collaboration and maintain synergy with parties internal and external to an organization (Eiriz \& Wilson, 2004; Gronroos, 1994). Dynamic capabilities is derived from the theory of resources based view (RBV) and examines more closely a company's ability to respond to the dynamics of the environment by developing a variety of sensing instruments, adaptation, and alignment (Alder \& Kwon, 2002; Teece, Pisano, \& Shuen, 1997). Meanwhile, social capital highlights the importance of networks among companies to form the capacity of a strong business cooperation network (Burt, 1992; Westerlund \& Rajala, 2010). The power of the network can be leveraged by empowering a collaborative network.

Network synergy capacity is the ability to combine the internal resources and strengths possessed by a number of its main consumers to accelerate the achievement of business performance. Synergy capacity is owned by companies which realize the importance of working together to optimize improvement in the area of business performance (Connell \& Voola, 2007). They are always exploring the strengths and trying to understand the potential network capacity of the consumer (Smart \& Dudas, 2007). Meanwhile, strength is the power of the company's relationships with various parties within its range (Kohtamäki, Vesalainen, Henneberg, Naudé, \& Ventresca, 2012). Companies enable such relations to support the routine and incidental activities that they are not able to manage themselves (Wathne \& Heide, 2000). Network capacity synergy is a combination of power of integration and networking excellence that encourages companies to be able to complete the obstacles and business challenges beyond the standard capability of the company in general (Claro \& de Oliveira Claro, 2011).

The supplier's ability to synchronize its competitive strategy with the retailer's condition is crucial in order to maintain sustainable cooperation. The supplier may design a specific marketing strategy to 
respond to the pressure from its main competitors, such as the determination of product variety, price reductions, and market expansion share (Prior, 2012). Before the marketing strategy is executed the marketing division should first communicate with the retailer or customer (Yen, Wang, \& Horng, 2011). Frequently, suppliers revise their strategies if they encounter resistance in the early stages of the socialization of the marketing strategies. Therefore, network synergy requires the alignment of business planning steps between the supplier and the retailer in face of the products of competitors (Connell \& Voola, 2007). They should conduct competition in collaborative actions that indicate mutual supporting in achieving the company's objective such as sharing information, supporting each other's strategies, and enhancing constructive dependence (Mysen, Svensson, \& Payan, 2011; Svensson, 2004).

Cooperation synergy, which is based on the commitment of collaborative problem solving, boosts a company's marketing growth. Every company that is bound to an agreement seeks to comply with the agreed rules. Companies also try to not violate the norms that apply in business ethics although this provision has not been written in the agreement (Wathne \& Heide, 2000). Adhering to each other's principles and supporting the respective policies of each side accelerates the achievement of marketing performance which is result of marketing division activities (Ferrer, Santa, \& Bretherton, 2010). When business constraints emerge, companies focus on problem solving and avoid policies that only benefit one party. Moreover, they use their power to minimize the impact of losses in any alternative solution (Mysen et al., 2011). Based on this discussion, a hypothesis is determined as follows:

\section{$H_{1:}$ The greater the network synergy capacity, the better the marketing performance.}

\subsection{Trust-developing capability}

Trust-developing capability is defined as the ability of companies to use internal resources to convince partners about the importance of relationships. Trust is the willingness of the trustor to rely on the important actions of the trustee without any close attention from the trustor (Morgan \& Hunt, 1994). Trust in the context of cooperation is the belief of one party in the other party, that the other party will do what is expected (Lewicki \& Mcallister, 1998). Two parties who trust each other will not act in a way that is harmful to the other because they are aware of the rights and responsibilities of each (Laeequddin \& Sardana, 2010). Trust cannot be derived from momentary activities but must be built through a series of mutually reinforcing constructive activities (Allison, 1999). Thus, business trust can also be grown by developing a company's reputation to become open, fair, and professional (Jambulingam et al., 2011).

Trust can be developed through a variety of actions of fairness in addressing transaction fulfillment. Fairness is related to attention and feedback, and a balanced manner of delivery, for the interests of the parties who are in the relationship (Soueksakit, 2013). In the early stages of trust development, the consumer is trying to assess the extent to which the company can be trusted by buying a small quantity of products (Kim et al., 2013). If any disagreement in the business can be resolved according to principles of justice, then the consumer's trust in the company will increase (Wathne \& Heide, 2000). Companies should not be tempted to perform opportunistic activities that only benefit the company because the consumer will be worried about the company's actions in normal conditions (Ahimbisibwe et al., 2012). Companies that are capable of maintaining fairness when they are in a position to carry out opportunistic activities send a strong message that the company always wants to maintain the relationship under any circumstances, whether in easy circumstances or difficult situations (Laeequddin \& Sardana, 2010). In addition, through the affective aspects such as fairness and honesty, trust can be nurtured through policies of professionalism such as providing experienced sales personnel, contacting 
the consumer on time, presenting detailed information about the quality of products, and providing a delivery fleet (Tournois, 2013).

Companies which understand the importance of building business trust are able to serve consumers wholeheartedly. They realize that trust is not the goal of their marketing programs, but rather it is a gateway towards building further relationships (Wagner et al., 2011). Companies should design programs that are better suited to serve the consumer's needs. If a company has already gained the trust of the consumer, it can create marketing programs that are different from those of its competitors and more beneficial to the two parties (Todeva \& Knoke, 2005). The marketing team, through the sales staff, can request support from the consumer to ensure they already have the right marketing program, which if conducted together, will provide a huge benefit to both (Sirdeshmukh, Singh, \& Sabol, 2006). When trust in business becomes the foundation for cooperation, a company is able to provide customized services to achieve customer satisfaction (Ha et al., 2011). This idea determines the following hypothesis:

\section{$H_{2:}$ The greater the trust-developing capability, the more excellent the service commitment}

Business trust enhances a company's capability to strengthen the consumer's competitive position. The understanding between the company and the consumer in facing the dynamics of business prompts the company to provide a variety of resource strengths for the consumer (Koza \& Dant, 2007). The company is committed to bearing some of the consumer's risk by transferring to the consumer some of its competitive advantages, such as product quality, low price, and supply sustainability. If the consumer is stronger, this in return will benefit the company, leading to an incremental increase in strength (Connell \& Voola, 2007). Companies do not want the consumer's trust to decrease because this condition will affect the commitment of the implementation of a marketing program which is being developed by the company (Prior, 2012). If the effort to develop trust does not work, the company loses a great deal of investment related to the transferal of its competitive advantage to the consumer (Svensson, 2004). Therefore, companies should maintain efforts of trust-developing in order for the activities of strengthening their competitive position to progress well (Claro \& de Oliveira Claro, 2011). Considering this argument, the hypothesis proposed is as follows:

\section{$H_{3:}$ The greater the trust-developing capability, the stronger the competitive position.}

Strong trust between the company and the customer can create better mutual cooperation. If the customer believes that the company is able to maintain a committed relationship, the customer will be willing to develop valued cooperation (Turner et al., 2000). Hence, the company can also develop more fruitful cooperation even if the program requires a huge amount of investment (Kohtamäki et al., 2012). Companies that are able to improve business relationships understand how to strengthen cooperation by combining the respective potential of both parties (Connell \& Voola, 2007). The effect of a trusted relationship encourages the application of company skills such as joint problem solving and competitive strategy adjustments (Ha et al., 2011). Trust relationships that are very strong occasionally ignore objective considerations causing companies to worry more about matters that would lead to the breakdown of the relationship rather than the risks that may arise as a result of the decisions made (Izquierdo \& Cillian, 2004). Therefore, companies must try to coordinate the requirements of their customers so that every business decision provides mutual benefit (Wathne \& Heide, 2000). Based on these considerations, the proposed hypothesis is as follows:

\section{$H_{4:}$ The greater the trust-developing capability, the greater the network synergy capacity.}




\subsection{Competitive position strengthening}

Competitive advantage refers to the internal resources that are obtained through sustainable business processes which make a company more valuable than its competitors. Competitive advantage may be in the form of either tangible assets or intangible assets (Wagner et al., 2011). Competitive advantage in the form of tangible assets includes product quality, price advantage, and size of delivery fleet (Kannan $\&$ Tan, 2006) while competitive advantage in the form of intangible assets includes image, reputation, network marketing, and innovation skills (Koufteros, Vickery, \& Droge, 2012). Competitive advantage is the output of the various activities of companies that comply with the quality process (Prior, 2012). Competitive advantage is not obtained through an instant process, but needs to pass through a variety of unique activities which take a certain amount of time (Li \& Ogunmokun, 2001). Companies that have a competitive advantage make them better and more able to survive and win the competition (Sørensen, 2009).

Competitive position strengthening is the supplier's ability to transfer a competitive advantage to the retailer so that the retailer gains a condition that is superior to its competitors. Suppliers with a competitive advantage can cooperate with retailers who have limited resources (Ha et al., 2011). Retailers, of course, prefer suppliers who support business continuity because a supplier which is oriented towards short-term relationships provides a greater risk, such as the delivery of lower quality products and uncertainty in the supply of product sustainability (Sheu et al., 2006). Suppliers that are able to convince retailers of the benefits of their competitive advantage gain real support (Kim et al., 2013). Retailers may even be willing to form an exclusive relationship by not cooperating with other suppliers (Laeequddin et al., 2010). Even though an exclusive relationship makes the retailer's bargaining position weaker, it means that the supplier avoids actions that are harmful to the business partner (Wathne \& Heide, 2000).

Suppliers that are able to seize a tendency to cooperate with retailers have an opportunity to involve retailers in mutualistic marketing programs. In principle, the intensity of cooperation occurs if there is initiative by either one or both sides to cooperate (Kim et al., 2013). One of the parties may act as the initiator of the cooperation, after taking note of a suitable degree of commitment of the other party (Walter \& Ritter, 2003). In the next stage, the two sides actively seek to engage in a relationship, because they understand that there is much mutual benefit to be gained (Sinkovics \& Roath, 2004). A supplier will endeavor to exploit its internal resources in order that the various areas of potential of the company can be transformed into real competitive advantages. Suppliers which deliver their competitive advantage quickly also obtain a fast response from the retailer (Turner et al., 2000). Likewise, suppliers which deliver all their competitive capabilities to the retailer in full power receive commensurate feedback (Corsten \& Felde, 2005). Based on these ideas, the hypothesis is determined as follows:

\section{$H_{5}$ : The greater the competitive position strengthening, the greater the network synergy capacity}

A supplier's competency which strengthens the competitive position of the retailer affects its marketing performance. Suppliers which are committed to improving the competitive advantage of the retailer are preferred as business partners because they have the ability to achieve a better competitive position through these advantages (Ha et al., 2011; Kim et al., 2013). If a supplier is able to deliver products with more competitive prices, better quality, and a faster service, the number of the supplier's consumers will grow enormously (Johnston \& Kristal, 2008; Kracklauer, Passenheim, \& Seifert, 2001). Reputed suppliers are able to convince retailers that their supply will be delivered with excellence and according to the wishes of the retailer (Squire, Cousins, Lawson, \& Brown, 2009). Likewise, an increase in the 
number of retailers will be followed by an increase in the value of sales (Tournois, 2013). Based on these ideas, the hypothesis is determined as follows:

\section{$H_{6}:$ The greater the competitive position strengthening, the better the marketing performance}

\subsection{Excellent service commitment}

Excellent service commitment is the continuous effort of a company to deliver its products and provide its service consequences with a wholehearted approach. Companies are able to develop a management system which enables the various activities of consumer service to be well-operated (Abramson \& Ai, 1998; Svensson, 2004). Customized services are already attached to many companies because companies are aware that good product delivery is a business habit. A company's consumer service is not limited to delivering the product to the consumer, but more than that, how it is able to achieve consumer satisfaction (Lui \& Ngo, 2005). A company's employees also have the skills to serve the consumer quickly so they are able to fulfill the desires and attend to the complaints of the consumer (Bantham, 2010). They understand that consumer loyalty can be maintained if the consumer receives a service that is comparable with the value the consumer pays (Mysen et al., 2011).

Companies need to understand and resolve consumer complaints in an appropriate manner. Consumers may show real dissatisfaction through a variety of activities that are addressed directly to the company, or alternatively, the dissatisfaction may only be expressed in the form of talk circulating around the consumer's environment (Wathne \& Heide, 2000). Consumer complaints are an indication of consumer dissatisfaction that is manifested in the form of taking action on services that do not meet with the consumer's expectations (Hamer, 2006; Wathne \& Heide, 2000). A company should expect the emotions of a consumer in relation to this dissatisfaction to be demonstrated in a tangible form so that it can find out and rectify whatever services are not optimal (Schmidt, Tyler, \& Brennan, 2007). Companies should respond to the various consumer complaints as an indication of concern for their services (Hunt, Arnett, \& Madhavaram, 2006). Companies often place the responsibility for dealing with complaints on a separate division called a consumer service center, which is a separate part of the marketing department (Bantham, 2010).

A supplier that is able to maintain its commitment of service to the retailer has a greater opportunity of establishing cooperation. Service commitment is a positive signal that the company has a professional power to conform to the needs of its partner (Siguaw et al., 1998). Service commitment is also a form of trust that the partner is supporting the success of the marketing program (Jones et al., 2010). A company needs to prepare its employees properly in order to deliver a well-prepared service. The company should also provide employees with communication skills and emotional maturity so that they are able to empathize with and resolve the retailers' complaints in a professional manner (Yen et al., 2011). Retailers who complain about a service being uncomfortable and have a negative perception of the supplier's communication techniques do not tend to show courtesy (Walter \& Ritter, 2003). Suppliers who have an advantage in the complaint management system have a greater chance of designing cooperative programs which involve the retailer actively (Connell \& Voola, 2007; Corsten \& Felde, 2005). Based on these considerations, the hypothesis is stated as follows:

\section{$H_{7:}$ The greater the excellent service commitment, the greater the network synergy capacity}

Excellent service commitment has the ability to improve marketing performance. Companies that are able to serve customers well will receive a positive response in the form of an increase in the number of 
products purchased (Tournois, 2013). Customers buy more products because the value of the products obtained exceeds their expectations (Morgan, 2012). There is an erroneous viewpoint which believes that a good service is an activity that burdens a company financially (Moore, Ratneshwar, \& Moore, 2012). This idea views service from a short term perception (Hamer, 2006). Quality of service is an investment which can produce an impact that is enjoyed by the company, namely in the form of consumer satisfaction or loyalty (Moore et al., 2012). Quality of service is also a long-term investment because it develops corporate reputation (Schmidt et al., 2007). Companies with a good reputation have the power to increase sales and expand their market share (Castro et al., 2006; Wagner et al., 2011). Paying attention to these ideas, the hypothesis constructed is as follows:

\section{$H_{8}:$ The greater the excellent service commitment, the better the marketing performance}

Various hypotheses based on previous research studies have formed a research model that is complete. This research model directs our attention primarily to the renewal variable of the research, namely network synergy capacity, followed by the determination of the antecedent variables and it's consequents (figure 1).

Figure 1: Research Model

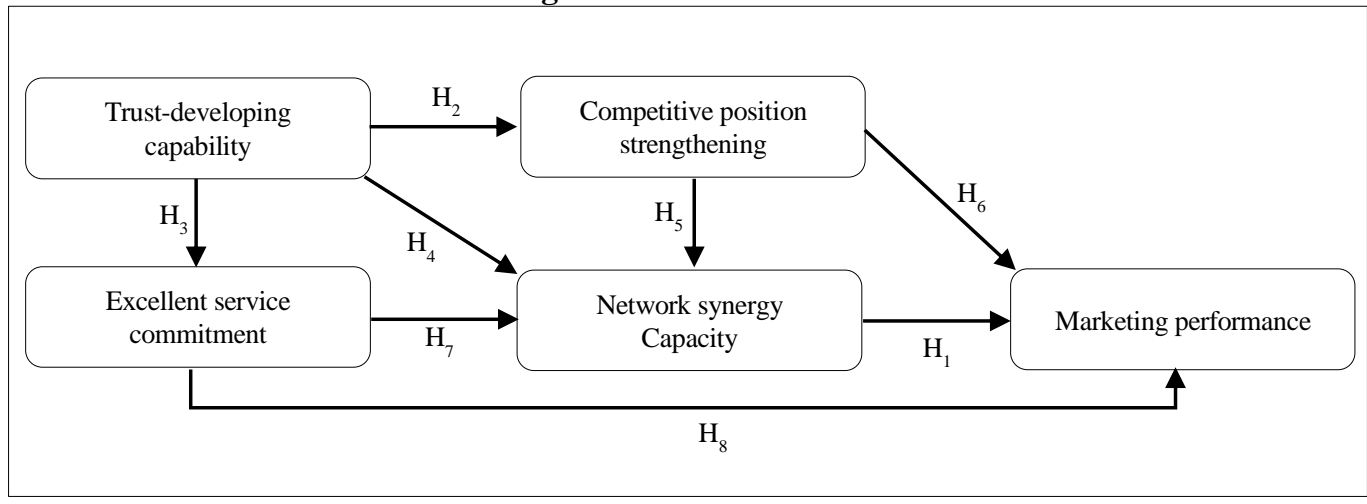

\section{METHODOLOGY}

\subsection{Data Collection}

A survey of a number of companies was conducted to test the hypotheses of the study. The subject of the study is the owners or managers of the selected companies which operate in the field of distribution of various types of products, such as building materials, food and beverages, garments, chemical products and electronics. The companies, all of which are located in Central Java, Indonesia, are agents of factories that sell to wholesalers or small traders. Based on information obtained from the Department of Industry and Commerce (Dinperindag) in Central Java, Indonesia, it was found that in 2015 there were 950 companies acting as agents for various types of products, spread throughout many large cities, including Semarang, Surakarta, Purwokerto, Tegal and Jepara. 320 of these companies were selected for the research as a random sample, taking into consideration factors such as the company's operations, business address, and contact number. In addition, the number of companies chosen exceeds the requirements of a survey sample of $10 \%$ and meets the minimum requirements to be processed with the 
SEM of 100 data. After selecting a number of companies as a sample, they were then contacted in various ways, either by telephone, letter, or a direct visit to the company office. Subsequently, questionnaires were presented to the owners or managers of the companies and the respondents were directed either by telephone or in a direct meeting to explain how the questionnaires should be completed.

\subsection{Indicators development}

The research variable indicators are determined based on the theoretical study of various research studies. Network synergy capacity is described by several indicators, namely the coordination of customer needs, solving problems together, developing sustainable relationships, and alignment of competitive strategies (Claro \& de Oliveira Claro, 2011; Connell \& Voola, 2007; Ferrer et al., 2010; Svensson, 2004; Wathne \& Heide, 2000). Trust-developing capability is measured by three major indicators, namely honesty of information delivery, fulfillment, and professional attitude (Hsu \& Kannan, 2008; Jambulingam et al., 2011; Laeequddin et al., 2010; Mysen et al., 2011). Meanwhile, marketing performance is measured by three indicators, namely the value of sales, sales volume, and sales growth (Avlonitis \& Salavou, 2007; Morgan, 2012).

The antecedent variables of network synergy capacity also could be represented by a number of relevant indicators. The competitive position strengthening variable is explained by three indicators, namely offering competitive prices, product quality reputation, and sustainability of supply (Kannan \& Tan, 2006; Koufteros et al., 2012; Prior, 2012; Wagner et al., 2011). The excellent service commitment variable is measured by three indicators, namely the speed of complaint resolution, suitability complaints response, and timely delivery (Castro et al., 2006; Lui \& Ngo, 2005; Mysen et al., 2011).

\section{DATA ANALYSIS}

\subsection{Normalize data}

To normalize the data, administrative and statistical procedures were done so that they could be processed by AMOS software eligibility. The abnormal data have great potential to produce low level of goodness of fit so that some coefficients of relationship between variables couldn't be final result (Hair, Arderson, Tatham, \& Black, 2009). There are some steps to normalize data. First, a number of respondents were eliminated from the sample list after the administration selection process was complete. A series of screening and trimming stages were also used to validate the respondents' consistency in answering the questionnaires. Out of 330 respondents, only 292 respondents answered the questionnaires in full, while 38 questionnaires were declared unfit due to their incomplete answers. Second, through an analysis of the determined outlier and an evaluation of question consistency of the respondents, 29 respondents were found to be inconsistent so that the data needed to be eliminated from the subsequent stage of processing. The normality value of the data obtained by AMOS shows a level of normality that fulfills the necessary terms. The univariate normality of the all the indicators fulfills the necessary requirements. These are on the scale of values c.r skewness and kurtosis $-2.548<$ normality value $<+2.548$ (table 1 ). The multivariate normality presents at -1.808 which confirms the normally distributed data. The number of final respondents to be processed by SEM is 263 companies, in which the composition of distributed products is $25 \%$ building materials, $25 \%$ food and beverages, $20 \%$ garments, $15 \%$ chemical products, and $15 \%$ electronics. 
Table 1: Construct Validity

\begin{tabular}{|c|c|c|c|c|c|c|}
\hline \multirow[b]{2}{*}{ Indicators } & \multicolumn{2}{|c|}{ Before normalized } & \multicolumn{2}{|c|}{ After normalized } & \multirow[b]{2}{*}{$\begin{array}{l}\text { Factor } \\
\text { loading }\end{array}$} & \multirow[b]{2}{*}{$\alpha$-cronbach } \\
\hline & $\begin{array}{c}\text { cr. } \\
\text { skewness }\end{array}$ & $\begin{array}{c}\text { cr. } \\
\text { kurtosis }\end{array}$ & $\begin{array}{c}\text { cr. } \\
\text { skewness }\end{array}$ & $\begin{array}{c}\text { cr. } \\
\text { kurtosis }\end{array}$ & & \\
\hline Network synergy capacity & & & & & & 0.861 \\
\hline Coordination of customer needs & $-0,797$ & $-1,449$ & -0.396 & -2.149 & 0.801 & \\
\hline Solving problems together & $-1,146$ & $-2,131$ & -0.879 & -1.261 & 0.834 & \\
\hline Developing sustainable relationships & $-0,945$ & $-1,890$ & 0.129 & -2.241 & 0.752 & \\
\hline Alignment of competitive strategies & $-6,298$ & 0,834 & -2.059 & -0.427 & 0.732 & \\
\hline Trust-developing capability & & & & & & 0.815 \\
\hline Honesty of information delivery & $-3,038$ & 1,238 & -2.382 & -0.525 & 0.713 & \\
\hline Fulfillment & $-4,526$ & $-2,702$ & -0.960 & -2.215 & 0.842 & \\
\hline Professional attitude & $-0,647$ & 1,838 & -0.946 & 0.803 & 0.772 & \\
\hline Competitive position strengthening & & & & & & 0.821 \\
\hline Offering competitive prices & $-2,304$ & 1,624 & -0.876 & -1.628 & 0.821 & \\
\hline Product quality reputation & $-0,780$ & 0,361 & -1.977 & -0.174 & 0.792 & \\
\hline Sustainability of supply & $-3,134$ & 3,607 & -0.104 & -1.117 & 0.723 & \\
\hline Excellent service commitment & & & & & & 0.792 \\
\hline Speed of complaint resolution & $-3,403$ & 0,165 & -2.190 & 0.782 & 0.744 & \\
\hline Suitability of complaint response & $-2,396$ & 1,778 & -1.757 & 0.067 & 0.753 & \\
\hline Timely delivery & $-4,121$ & 5,143 & -1.607 & -0.105 & 0.761 & \\
\hline Marketing performance & & & & & & 0.756 \\
\hline Values of sales & $-4,053$ & $-1,370$ & -1.378 & -0.652 & 0.713 & \\
\hline Sales volume & $-4,080$ & $-0,906$ & -1.600 & -2.419 & 0.702 & \\
\hline Sales growth & $-5,226$ & $-0,041$ & -0.290 & -0.907 & 0.741 & \\
\hline Multivariate normality & 18, & 297 & -1.8 & 808 & & \\
\hline
\end{tabular}

\subsection{Construct validity}

The qualification of the goodness indicator of the variables should exceed the validation value, which is the minimum value of the factor loading and $\alpha$-cronbach of 0.7 . The factor loading values can be obtained by testing a measurement model with AMOS while $\alpha$-cronbach can be obtained through SPSS (table 1). The research variable indicators, which are determined based on the theoretical study of various research studies, meet the level necessary for validity as a questionnaire measuring instrument. Smallest value of factor loading of indicator and $\alpha$-cronbach of variable respectively 0.702 and 0.756 . The facts verify that data can be proceed to next steps.

\subsection{Structural model analysis}

The testing of the research model through AMOS shows a high level of compatibility of the model (Table 2). The number of important compatibilities of the model, such as the significance value of 0.05 , which is greater than the required 0.005 , the small chi-square value of 119.810 and the RMSEA below 0.08 all indicate that the model is able to represent the perception of the respondents. This fact is reinforced by a number of parameters of goodness of fit of the model which are greater than 0.9 , such as $\mathrm{AGFI}=0.924, \mathrm{GFI}=0.947, \mathrm{TLI}=0.984, \mathrm{GFI}=0.947$ and $\mathrm{CFI}=0.988$. The adequacy of the data to be processed by AMOS shows a hoelter value of 287 , well above the number of samples, 263 . The goodness of fit model shows high compatibility between the empirical model and the hypothesized model. 
The testing of the model with AMOS software at an acceptance probability of $10 \%$ on a critical ratio (cr) of parameter estimation value produces a coefficient estimation that supports the entire relationship between the hypothesized variables (table 2). there is a positive influence of synergy network capacity on marketing performance $\left(\mathrm{H}_{1}\right)$. Suppliers which are able to manage cooperation in synergy with retailers are able to improve their marketing performance (Mysen et al., 2011). Companies that are willing to harmonize their strategies to compete with retailers without ignoring the interests of both gain the enthusiastic support of customers for continued relationships with the company (Wathne \& Heide, 2000). The enthusiasm to build relationships with retailers is felt by the company in various parameters such as increasing the number of customers and also product selling volume (Ferrer et al., 2010) Companies which seek to coordinate the needs of their various customers gain a valuable response from their business partners which means that product purchase can be optimally satisfied (Mysen et al., 2011).

Trust-developing capability effects positively on competitive position strengthening $\left(\mathrm{H}_{2}\right)$. Suppliers that are able to provide information about their products openly and honestly have better opportunities to cooperate more deeply with their retailers (Todeva \& Knoke, 2005). Likewise, It is also evident that trust-developing capability effect positively on excellent service commitment $\left(\mathrm{H}_{3}\right)$. Suppliers which are able to act professionally have a commitment to serving their retailers. If a company is able to build cognitive trust and affective trust, the company will more easily be able to develop a variety of marketing programs (Koza \& Dant, 2007).

Trust-developing capability influence on network synergy capacity positively $\left(\mathrm{H}_{4}\right)$. Suppliers which have a good reputation will provide many opportunities to create mutually beneficial cooperation. At the initial stage of cooperation, suppliers are willing to bear business risks such as low profit levels and high delivery costs to show their willingness to continue in the relationship (Turner et al., 2000). After passing through the process of shaping their perception of trust, retailers are willing to accept price adjustments, and shipping costs are determined by the supplier (Connell \& Voola, 2007). When the trust of the retailer reaches a certain level, the retailer then has the courage to accept various offers of cooperation from the supplier (Wathne \& Heide, 2000).

There is a positive impact of competitive position strengthening on network synergy capacity $\left(\mathrm{H}_{5}\right)$. A supplier which has power in aspects of price and quality of products has a greater opportunity of establishing broader cooperation with its retailers (Kim et al., 2013). This does not mean that the supplier must sell quality products at a low price (Walter \& Ritter, 2003). However, the supplier can create a positive perception of selling quality goods at a price that corresponds to the level of the retailer's market position (Turner et al., 2000).

Competitive position strengthening have a great impact on marketing performance $\left(\mathrm{H}_{6}\right)$. Suppliers which have an advantage of competitive position strengthening such as the sustainability of the supply of products may develop more intensive cooperation with retailers (Ha et al., 2011). Retailers assume that the sustainability of the supply of products from suppliers gives the retailers power to serve their end-user's needs (Kim et al., 2013). Retailers accept various marketing programs from their suppliers even though the retailers have to bear the additional investment resources such as the cost of inventory, training, and knowledge of warehouse expansion (Johnston \& Kristal, 2008). The additional investment resources in specific business areas are not considered to be the cost of investment, but rather are positioned as an entry barrier for competitors who wish to enter the business field. The proactive strengthening efforts support to achieve marketing performance. 
Table 2: Results of relationships between variables

\begin{tabular}{llccc}
\hline \hline No & Relationship between variables & $\begin{array}{c}\text { Standardized } \\
\text { Regression }\end{array}$ & P & Results \\
\hline 1 Network synergy capacity $\rightarrow$ Marketing performance & 0.301 & 0.009 & $\mathrm{H}_{1}$ accepted \\
2 Trust-developing capability $\rightarrow$ Competitive position strengthening & 0.594 & 0.000 & $\mathrm{H}_{2}$ accepted \\
3 Trust-developing capability $\rightarrow$ Excellent service commitment & 0.683 & 0.000 & $\mathrm{H}_{3}$ accepted \\
4 Trust-developing capability $\rightarrow$ Network synergy capacity & 0.247 & 0.012 & $\mathrm{H}_{4}$ accepted \\
5 Competitive position strengthening $\rightarrow$ Network synergy capacity & 0.290 & 0.000 & $\mathrm{H}_{5}$ accepted \\
6 Competitive position strengthening $\rightarrow$ Marketing performance & 0.259 & 0.003 & $\mathrm{H}_{6}$ accepted \\
7 Excellent service commitment $\rightarrow$ Network synergy capacity & 0.398 & 0.000 & $\mathrm{H}_{7}$ accepted \\
8 Excellent service commitment $\rightarrow$ Marketing performance & 0.346 & 0.000 & $\mathrm{H}_{8}$ accepted \\
\hline \hline
\end{tabular}

Note: chi-square: 19.810, p: AGFI: 0.924, GFI: 0.947, TLI: 0.984, CFI: 0.988, RMSEA: 0.031, Hoelter: 287

Excellent service commitment has a positive influence on network synergy capacity $\left(\mathrm{H}_{7}\right)$. Suppliers with a variety of consumer service activities are able to persuade retailers to joint mutualistic cooperation programs (Jones et al., 2010). Suppliers are aware that business success is not only determined by the quality of the product, but also by the number of different services that support product delivery (Yen et al., 2011). Retailers are willing to accept the supplier's collaborative invitations if the supplier provides excellent services such as on-time delivery, complaint resolution, and defective product (Connell \& Voola, 2007; Corsten \& Felde, 2005).

Excellent service commitment effect positively on marketing performance $\left(\mathrm{H}_{8}\right)$. Suppliers which care about quality services receive feedback from their retailers in the form of additional varieties of product sales and an increase in the number of products sold (Tournois, 2013). Suppliers who are able to meet the needs of the consumer manage to gain a number of retailers who are very loyal to the supplier (Morgan, 2012). Suppliers should direct the service quality improvement activities towards long-term marketing programs since retailers evaluate the level of the company's commitment to implementing these programs for improving the quality of service (Moore et al., 2012). Programs designed to improve the service quality are also programs to be implemented by the rest of the company so as to accelerate the benefit of these activities for supporting the achievement of customer satisfaction (Hamer, 2006).

\subsection{Pathway analysis}

The priority pathways for improving marketing performance can be determined by identifying the values of the path coefficients passing through the relationships of three or more variables (Table 3). The path coefficient values can be determined by multiplying the values of each of the standardized coefficients. There are five alternatives that increase marketing performance through three or four variables. Based on the path coefficient values, the priority for improving marketing performance is reinforced on pathway 1 which passes through trust-developing capability, excellent service commitment, and marketing performance with an intermediation effect value of 0.236 . The second priority pathway which has the ability to increase marketing performance passes through trustdeveloping capability, competitive position strengthening, and marketing performance with an intermediation effect value of 0.154 .

Pathways for increasing marketing performance that pass through network synergy capacity have a low intermediation effect. The third pathway which passes through trust-developing capability, excellent service commitment, network synergy capacity, and marketing performance shows a value of intermediation effect of 0.082 . The fourth pathway which passes through trust-developing capability, network synergy capacity, and marketing performance has an intermediation effect of 0.074 . 
Meanwhile, the fifth pathway which passes through trust-developing capability, competitive position strengthening, excellent service commitment, network synergy capacity, and marketing performance has a low intermediation effect, with a value of only 0.052 . This low intermediation effect is caused by the standardized regression between network synergy capacity and the gateway variable, namely trustdeveloping capability, which has low value of 0.247. In addition, standardized regression between network synergy capacity and its consequence variable, marketing performance, has a relatively low value of 0.301 . If the pathway to increase marketing performance is analogous to transportation traffic, then an intervening variable is the terminal for the transportation media. Excellent service commitment has the most important role of all the terminals in the model, followed by the role of the terminal of the competitive position strengthening and network synergy capacity.

Table 3: Intermediation effect to improve marketing performance

\begin{tabular}{|c|c|c|c|c|c|c|c|c|c|}
\hline \multirow{2}{*}{ No } & \multirow{2}{*}{\multicolumn{5}{|c|}{ Pathway to improve marketing performance }} & \multicolumn{3}{|c|}{ Direct effect value } & \multirow{2}{*}{$\begin{array}{c}\text { Intermediation } \\
\text { effect }\end{array}$} \\
\hline & & & & & & 1 & 2 & 3 & \\
\hline $\begin{array}{l}1 \text { Trust- } \\
\text { developing } \\
\text { capability }\end{array}$ & $\begin{array}{ll}\rightarrow & \text { Excellent } \\
(1) & \text { service } \\
& \text { orientation }\end{array}$ & $\begin{array}{ll}\rightarrow & 1 \\
(2) & 1\end{array}$ & $\begin{array}{l}\text { Marketing } \\
\text { performance }\end{array}$ & & & 0.683 & 0.346 & & 0.236 \\
\hline $\begin{array}{l}2 \text { Trust- } \\
\text { developing } \\
\text { capability }\end{array}$ & $\begin{array}{ll}\rightarrow & \text { Competitive } \\
\text { (1) } & \text { position } \\
& \text { strengthening }\end{array}$ & $\begin{array}{ll}\rightarrow & 1 \\
(2) & 1\end{array}$ & $\begin{array}{l}\text { Marketing } \\
\text { performance }\end{array}$ & & & 0.594 & 0.259 & & 0.154 \\
\hline $\begin{array}{l}3 \text { Trust- } \\
\text { developing } \\
\text { capability }\end{array}$ & $\begin{array}{l}\rightarrow \text { Excellent } \\
\text { (1) } \\
\text { service } \\
\text { orientation }\end{array}$ & $\begin{array}{l}\rightarrow \\
(2)\end{array}$ & $\begin{array}{l}\text { Network } \\
\text { synergy } \\
\text { capacity }\end{array}$ & $\begin{array}{l}\overrightarrow{(3)} \\
(3)\end{array}$ & $\begin{array}{l}\text { Marketing } \\
\text { performance }\end{array}$ & 0.683 & 0.398 & 0.301 & 0.082 \\
\hline $\begin{array}{l}4 \text { Trust- } \\
\text { developing } \\
\text { capability }\end{array}$ & $\begin{array}{ll}\rightarrow & \text { Network } \\
(1) & \text { synergy } \\
& \text { capacity }\end{array}$ & $\begin{array}{ll}\rightarrow & 1 \\
(2) & 1\end{array}$ & $\begin{array}{l}\text { Marketing } \\
\text { performance }\end{array}$ & & & 0.247 & 0.301 & & 0.074 \\
\hline $\begin{array}{l}5 \text { Trust- } \\
\text { developing } \\
\text { capability }\end{array}$ & $\begin{array}{ll}\rightarrow & \text { Competitive } \\
\text { (1) } & \text { position } \\
& \text { strengthening }\end{array}$ & $\begin{array}{l}\rightarrow \\
(2) \\
\end{array}$ & $\begin{array}{l}\text { Network } \\
\text { synergy } \\
\text { capacity }\end{array}$ & $\begin{array}{l}\overrightarrow{3} \\
(3)\end{array}$ & $\begin{array}{l}\text { Marketing } \\
\text { performance }\end{array}$ & 0.594 & 0.290 & 0.301 & 0.052 \\
\hline
\end{tabular}

\section{CONCLUSION}

The research model reflects the supplier's behavior in delivering the product to the retailer. The model positions trust-developing capability as an entry point into the model and marketing performance as the ultimate goal. The process section of this research model consists of three intermediation variables, namely competitive position strengthening, excellent service commitment, and network synergy capacity. The model defines systematic marketing guidance to optimize the supplier's internal resources for influencing the retailer's business decisions. The supplier should possess trust-developing capability as a basic skill for building relationships. The supplier also needs to develop more advanced skills for maintaining relationships through excellent service commitment, competitive position strengthening and network synergy capacity.

All the hypotheses in this study are empirically supported. Trust-developing capability has a significant effect on its three consequence variables, namely competitive position strengthening, excellent service commitment and network synergy capacity. Suppliers need to understand about business confidence and how to cultivate trust with business partners. Trust is a reflection of the reputation of the company, and as such, the marketing department should endeavor to maintain its reputation through optimal marketing activities. All of the intermediation variables show a level of significance in their relationships 
with both antecedent and consequence variables. The three intermediation variables are affected by trust-developing capability. The three intermediation variables also affect marketing performance.

Network synergy capacity has a low capacity terminal role. Intermediation function in the context of transportation acts as a terminal which is a place for a transport medium to stop temporarily before it reaches its final destination. A terminal plays an important role if the terminal is able to influence the effectiveness of pathways to achieve specific goals. A terminal variable becomes a significant intermediation variable because it supports the achievement of the marketing performance. On the contrary, an intermediation variable is not a priority of preference if its terminal function is not able to effectively encourage marketing performance achievements. The pathways passing through network synergy capacity (pathway 3, pathway 4 and pathway 5) have a lower intermediation effect than the pathways that are followed by excellent service commitment (pathway 1) or competitive position strengthening (pathway 2). Network synergy capacity is positioned as the last alternative as a terminal for achieving marketing performance. It is below the two main terminal variables: excellent service commitment and competitive position strengthening.

Activities related to network synergy have been demonstrated through excellent service commitment and competitive position strengthening. Although network synergy capacity plays only a small role in influencing the pathway for improving marketing performance, it cannot be ignored in the effort to establish a relationship. Each supplier still needs a network for maintaining its marketing relationships. The intermediation effect of excellent service commitment, which has a value above that of the network synergy capacity, illustrates that the supplier's ability to provide services to retailers already includes network maintenance activities. Likewise, the intermediation effect of competitive position strengthening, which has a value above that of network synergy capacity, shows that the ability of the supplier to strengthen its competitive position already represents the company's activities to establish synergy with its business partners.

The concept of network synergy capacity contributes to the development of the business network theory. A number of researchers make similar statements, that the network plays an important role in supporting business development in response to limited resources and strong as well as hard competition (Claro \& de Oliveira Claro, 2011; Westerlund \& Rajala, 2010). The characteristics of the network are explained separately as having an adaptive approach (Brennan, Turnbull, \& Wilson, 2003), synergic actions (Connell \& Voola, 2007) and integrative collaboration (Forslund \& Jonsson, 2009). A construct for the network which matches these current challenges has yet to be identified in a comprehensive concept. This research synthesizes the new paradigm of the network, namely that collaboration is encouraged not only to achieve synergy but also so that all parties have a commitment to enhance responsiveness towards each other (Jayachandran, Hewett, \& Kaufman, 2004). Network synergy capacity can be proven theoretically to be a complementary element which completes the body of knowledge about the network.

\section{MANAGERIAL IMPLICATIONS AND FUTURE RESEARCH}

Suppliers can enhance trust-developing capability by cultivating relational skills that improve cognitive trust and affective trust. Suppliers should act professionally both in providing information about products and in fulfilling the needs of retailers. Suppliers must also maintain affective trust by conveying information objectively and sustaining close relationships. If contact with retailers is represented by sales staff, the supplier should provide sales staff with various abilities, such as communication skills, 
product and price knowledge, as well as persuasion skills. The schedule of visits to the retailer's sales staff should be well-managed by the supplier because a higher intensity of meetings with consumers greatly affects the maintenance of trust.

Orientation to excellent services can be enhanced through the fulfillment of services provided for retailers. Each service should be evaluated in terms of its degree of quality, including the speed and accuracy with which a supplier delivers the service to the retailer. If the supplier receives a complaint from a retailer, the supplier must respond actively to find a solution. Suppliers should hold routine meetings to evaluate marketing programs and handle consumer complaints that require coordination between the marketing department and other departments. If retailers complain about product quality, the supplier needs to involve the quality control department to improve product quality in the next delivery.

Suppliers have the ability to improve their competitive position strengthening through a commitment to the procurement of products that meet the requirements of quality, price, and quantity. Suppliers should cooperate with reputable manufacturers who can also guarantee sustainability of supply. Suppliers should manage the purchasing department well so that it can cooperate with the manufacturers responsible for supporting the continuity of product distribution.

Suppliers should evaluate the achievements of synergy programs so that their competitive strategies synchronize with the retailer's marketing strategies. Suppliers can create innovative synergy programs that have a real impact on the improvement of marketing performance. Synergy programs can be directed towards improving the coordination between customer needs and the commitment to problem solving because these activities play a major role in establishing network synergy capacity. Products offered by suppliers should correspond to the needs of the retailers. Suppliers should always monitor the sales fluctuation of the retailer's products so that they are able to design a suitable product line for the retailer's needs.

This study proposes a number of recommendations for future research based on its limitations. The suppliers businesses were very diverse in the nature of their products, and the marketing behavior of any field of endeavor has a certain degree of heterogeneity in its product characteristics. The characteristics of the products sold by the agents surveyed varied from products with extended durability, such as building materials, to those with limited durability, such as food and beverages. This research has not yet identified any differences in the marketing efforts of the various companies according to the various characteristics of the different products. Subsequent research studies should attempt to focus on companies that have homogeneity in terms of their product characteristics.

\section{REFERENCES}

Abramson, N. R., \& Ai, J. X. (1998). Practising relationship marketing in Southeast Asia: Reducing uncertainty and improving performance. Management International Review, 38(1), 113-143.

Ahimbisibwe, A., Muhwezi, M., \& Nangoli, S. (2012). Outsourced contracts, buyer-supplier trust, supplier opportunistic behaviour and supplier performance in Ugandan public procuring and disposing entities (PDEs). Journal of Public Procurement, 12(4), 435-470.

Alder, P. S., \& Kwon, S. W. (2002). Social capital: Prospects for a new concept. Academy of Management Review, 27(1), 17-40.

Allison, D. (1999). Making and acting upon trustworthiness as assestments in buyer-supller relations. University of Michigan: The Centre for Research on Social Organization. 
Ambrose, E., Marshall, D., \& Lynch, D. (2010). Buyer supplier perspectives on supply chain relationships. International Journal of Operations \& Production Management, 30(12), 1269-1290.

Avlonitis, G. J., \& Salavou. (2007). Entrepreneurial orientation of SMEs, product innovativeness and performance. Journal of Business Research, 30(60), 566-575.

Bantham, J. H. (2010). An exploratory study of satisfaction in buyer-seller partnerships. Journal of Consumer Satisfaction, Dissatisfaction and Complaining Behavior, 23(1), 1-30.

Batonda, G., \& Perry, C. (2003). Approaches to relationship development processes in inter-firm networks. European Journal of Marketing, 37(10), 1457-1484.

Brennan, D. R., Turnbull, P. W., \& Wilson, D. I. (2003). Dyadic adaptation in business-to-business markets. European Journal of Marketing, 37(11/12), 1636-1655.

Burt, R. S. (1992). Structural holes : the social structure of competition. Cambride: MA : Harvard University Press.

Castro, G. M. De, López, J. E. N., \& Sáez, P. L. (2006). Business and social reputation: Exploring the concept and main dimensions of corporate reputation. Journal of Business Ethics, 63(4), 361-370.

Claro, D. P., \& de Oliveira Claro, P. B. (2011). Networking and developing collaborative relationships: evidence of the auto-part industry of Brazil. Journal of Business \& Industrial Marketing, 26(7), 514-523.

Connell, J., \& Voola, R. (2007). Strategic alliances and knowledge sharing: synergies or silos? Journal of Knowledge Management, 11(3), 52-66.

Corsten, D., \& Felde, J. (2005). Exploring the performance effects of key-supplier collaboration: An empirical investigation into Swiss buyer-supplier relationships. International Journal of Physical Distribution \& Logistics Management, 35(6), 445-461.

Eiriz, V., \& Wilson, D. (2004). Research in relationship marketing antecedents, traditions and integration. European Journal of Marketing, 40(3/4), 45-65.

Ferrer, M., Santa, R., \& Bretherton, P. (2010). Relational factors that explain supply chain relationships. Asia Pacific Journal of Marketing and Logistics, 22(3), 419-440.

Forslund, H., \& Jonsson, P. (2009). Obstacles to supply chain integration of the performance management process in buyer-supplier dyads: The buyers' perspective. International Journal of Operations \& Production Management, 29(1), 77-95.

Gronroos, C. (1994). From marketing mix to relationship marketing. Journal of Management Decision, 32(5), 4-20.

Ha, B.-C., Park, Y.-K., \& Cho, S. (2011). Suppliers' affective trust and trust in competency in buyers : Its effect on collaboration and logistics efficiency. International Journal of Operation \& Production Management, 31(1), 56-77.

Hair, J. F., Arderson, R. E., Tatham, R. 1., \& Black, W. C. (2009). Multivariate data analysis (7 ${ }^{\text {th }}$ ed.). Prentice Hall.

Hamer, L. O. (2006). A confirmation perspective on perceived service quality. Journal of Services Marketing, 20(4), 219-232.

Hsu, C., \& Kannan, V. (2008). Information sharing, buyer-supplier relationship and firm performance. International Journal of Operations \& Production Management, 31(1), 56-77.

Hunt, S. D., Arnett, D. B., \& Madhavaram, S. (2006). For dynamic relationship marketing theory: a reply to Rese. Journal of Business \& Industrial Marketing, 21(2), 92-93.

Izquierdo, C. C., \& Cillian, J. G. (2004). The interaction of dependence and trust in long-term industrial relationships. European Journal of Marketing, 38(8), 974-994.

Jambulingam, T., Kathuria, R., \& Nevin, J. R. (2011). Fairness-trust-loyalty relationship under varying conditions of supplier-buyer interdependence. Journal of Marketing Theory and Practice, 19(1), $39-56$. 
Jayachandran, S., Hewett, K., \& Kaufman, P. (2004). Customer response capability in a sense-andrespon era: The Role of customer knowledge process. Academic of Marketing Science Journal, 32(3), 219-239.

Johnston, D. A., \& Kristal, M. M. (2008). The climate for co-operation: Buyer-supplier beliefs and behavior. International Journal of Operations \& Production Management, 28(9), 875-898.

Jones, S. C., Knotts, T. L., \& Udell, G. G. (2008). Market orientation for small manufacturing suppliers The importance of product-related factors. Journal of Business \& Industrial Marketing, 23(7), 443-453.

Jones, S. L., Fawcett, S. E., Fawcett, A. M., \& Wallin, C. (2010). Benchmarking trust signals in supply chain alliances: Moving toward a robust measure of trust. Benchmarking: An International Journal, 17(5), 705-727.

Kannan, V. R., \& Tan, K. C. (2006). Buyer-supplier relationships : The impact of supplier selection and buyer-supplier engagement on relationship and firm performance. International Journal of Physical Distribution \& Logistics Management, 36(10), 755-775.

Kim, S., Kim, N., Pae, J. H., \& Yip, L. (2013). Cooperate "and" compete: coopetition strategy in retailersupplier relationships. Journal of Business \& Industrial Marketing, 28(4), 263-275.

Kohtamäki, M., Vesalainen, J., Henneberg, S., Naudé, P., \& Ventresca, M. J. (2012). Enabling relationship structures and relationship performance improvement: The moderating role of relational capital. Industrial Marketing Management, 41(8), 1298-1309.

Koufteros, X., Vickery, S. K., \& Droge, C. (2012). The Effects of strategic supplier selection on buyer competitive performance in matched domain: Does supplier integration mediate the relationship. Journal of Supply Chain Management, 48(2), 93-115.

Koza, K. L., \& Dant, R. P. (2007). Effects of relationship climate, control mechanism, and communications on conflict resolution behavior and performance outcomes. Journal of Retailing, 83(3), 279-296.

Kracklauer, A., Passenheim, O., \& Seifert, D. (2001). Mutual customer approach: how industry and trade are executing collaborative customer relationship management. International Journal of Retail \& Distribution Management, 29(12), 515-519.

Laeequddin, M., \& Sardana, G. D. (2010). What breaks trust in customer supplier relationship? Management Decision, 48(3), 353-365.

Lewicki, R. J., \& Mcallister, D. J. (1998). Trust and distrust: New relationships and realities. Academy of Management Review, 23(3), 438-458.

Li, L-Y., \& Ogunmokun, G. O. (2001). The influence of interfirm relational capabilities on export advantage and performance: an ampirical analysis. International Business Review, 10(4), 399-420.

Lui, S. S., \& Ngo, H.-Y. (2005). The influence of structural and process factors on partnership satisfaction in interfirm cooperation. Group \& Organization Management, 30(4), 378-397.

Moore, M. L., Ratneshwar, S., \& Moore, R. S. (2012). Understanding loyalty bonds and their impact on relationship strength: A service firm perspective. Journal of Services Marketing, 26(4), 253-264.

Morgan, R. M. (2012). Marketing and Business Performance. Journal of the Academy of Marketing Science , 40(1), 102-119.

Morgan, R. M., \& Hunt, S. D. (1994). The commitment-trust theory of relationship marketing. Jurnal of Marketing, 58(3), 20-38.

Mysen, T., Svensson, G., \& Payan, J. M. (2011). Causes and outcomes of satisfaction in business relationships. Marketing Intelligence \& Planning, 29(2), 123-140.

Prior, D. D. (2012). The effects of buyer-supplier relationships on buyer competitiveness. Journal of Business \& Industrial Marketing, 27(2), 100-114.

Schmidt, S.-O., Tyler, K., \& Brennan, R. (2007). Adaptation in inter-firm relationships: classification, motivation, calculation. Journal of Services Marketing, 21(7), 530-537. 
Sheu, C., Yen, J. R., \& Chae, B. (2006). Determinants of supplier-retailer collaboration : evidence from an international study. International Journal of Operations \& Production Management, 26(1/2), 24-49.

Siguaw, J. A., Simpton, P. M., \& Baker, T. L. (1998). Effects of supplier market orientation on distributor market orientation and the channel relationship : the distributor perspective. Journal of Marketing, 62(3), 99-111.

Sinkovics, R. R., \& Roath, A. S. (2004). Strategic orientation, capabilities, and performance in manufacturer - 3PL relationships. Journal of Business Logistics, 25(2), 43-64.

Sirdeshmukh, D., Singh, J., \& Sabol, B. (2006). Consumer trust, value, and loyalty in relational exchanges. Journal of Marketing, 66(1), 15-37.

Smart, A., \& Dudas, A. (2007). Developing a decision-making framework for implementing purchasing synergy: a case study. International Journal of Physical Distribution \& Logistics Management, 37(1), 64-89.

Sørensen, H. E. (2009). Why competitors matter for market orientation. European Journal of Marketing, 43(5/6), 735-761.

Soueksakit, S. (2013). The Effect of fairness-based relationship quality on relationship performance and the moderating role of dependence. The Journal of American Business Review, 2(2), 197-205.

Squire, B., Cousins, P. D., Lawson, B., \& Brown, S. (2009). The effect of supplier manufacturing capabilities on buyer responsiveness: The role of collaboration. International Journal of Operations \& Production Management, 29(8), 766-788.

Svensson, G. (2004). Vulnerability in business relationships: The gap between dependence and trust. The Journal of Business \& Industrial Marketing, 19(7), 469-483.

Teece, D. J., Pisano, G., \& Shuen, A. (1997). Dynamic capabilities and strategic management. Strategic Management Journal, 18(7), 509-533.

Terpend, R., Krause, D. R., \& Dooley, K. J. (2011). Managing buyer-supplier relationships : Empirical patterns of strategy formulation in Industrial. Journal of Supply Chain Management, 47(1), 73-94.

Todeva, E., \& Knoke, D. (2005). Strategic alliances and models of collaboration. Management Decision, 43(2), 123-148.

Tournois, L. (2013). Total market orientation, customer value, and market performance from a dual perspective. Journal of Applied Business Research, 29(4), 1157-1173.

Tournois, M., Sahay, B. S., Sahay, V., \& Waheed, K. A. (2010). Measuring trust in supply chain partners' relationships. Measuring Business Excellence, 14(3), 53-69.

Turner, G. B., LeMay, S. A., Hartley, M., \& Wood, C. M. (2000). Interdependence and cooperation in industrial buyer-supplier relationships. Journal of Marketing Theory and Practice, 8(8), 16-24.

Wagner, S. M., Coley, L. S., \& Lindeman, E. (2011). Effects of supplier's reputation on future of buyer supplier relationship the mediating roles of outcome fairness and trust. Journal of Supply Chain Management, 47(2), 29-48.

Walter, A., \& Ritter, T. (2003). The influence of adaptations, trust, and commitment on value-creating functions of customer relationships. The Journal of Business \& Industrial Marketing, 18(4/5), 353-365.

Wathne, K. H., \& Heide, J. B. (2000). Opportunism in interfirm relationships : Forms, outcomes, and solutions. Journal of Marketing, 64(4), 36-51

Westerlund, M., \& Rajala, R. (2010). Learning and innovation in inter-organizational network collaboration. Journal of Business \& Industrial Marketing, 25(6), 435-442.

Yen, Y-X., Wang, E. S-T., \& Horng, D-J. (2011). Suppliers' willingness of customization, effective communication, and trust: a study of switching cost antecedents. Journal of Business \& Industrial Marketing, 26(4), 250-259. 